\title{
Aktivisme dan Kesukarelawanan dalam Media Sosial Komunitas Kaum Muda Yogyakarta
}

\author{
Ramma Wisnu Dewantara ${ }^{1}$ \\ Derajad S. Widhyharto ${ }^{2}$
}

\begin{abstract}
There has been a change in the way activism and volunteerism of the youth form social movement, which is namely from offline to online environment. This is closely related to the advancement of information technology, especially Web 2.0, that has made many social realities demonstrated by this new media. One of this new media is social media that is considered to have the advantage of being fast in distributing messages. Social media has also become a "new public space" for the youth to share or discuss any issue and even also be used as a means of revolution. The methods used in this new media research were in-depth interviews and focus group discussion. Its show result that, the Yogyakarta youth in various communities have successfully made the best use of the advantage of social media as means of balancing, reminder and supplement of the new youth movement.
\end{abstract}

\section{Keywords:}

activism; volunteerism; youth; social media.

\begin{abstract}
Abstrak
Aktivisme dan kesukarelawanan kaum muda dalam membentuk gerakan sosial telah mengalami pergeseran dari offline menuju online. Hal ini tidak terlepas dari perkembangan teknologi informasi terutama dengan munculnya Web 2.0 yang membuat banyak realitas sosial diperlihatkan oleh media baru tersebut. Salah satu turunan media baru ini adalah media sosial yang dianggap unggul dalam kecepatan mendistribusikan pesan. Media sosial juga menjadi "ruang publik baru" kaum muda untuk berbagi atau berdiskusi mengenai isu tertentu, bahkan sampai digunakan sebagai tuntutan revolusi. Metode yang digunakan dalam penelitian media baru ini adalah wawancara mendalam dan focus group discussion. Temuannya memperlihatkan bahwa kaum muda Yogyakarta, yang terhimpun dalam berbagai komunitas, berhasil memanfaatkan media sosial sebagai penyeimbang, pengingat, dan suplemen gerakan baru komunitas kaum muda.
\end{abstract}

\section{Kata Kunci:}

aktivisme; kesukarelawanan; kaum muda; media sosial.

\section{Pendahuluan}

Teknologi informasi dalam beberapa tahun terakhir mengalami perkembangan yang begitu pesat. Kondisi ini mengindikasikan perubahan dan tuntutan interaksi dengan cenderung menggunakan media komunikasi

\footnotetext{
1 Mahasiswa Magister Manajemen Pembangunan Sosial Departemen Sosiologi Universitas Indonesia. Email: ramma.dewantara@gmail.com

2 Dosen Departemen Sosiologi Fakultas Ilmu Sosial dan Ilmu Politik, Universitas Gadjah Mada
} 
yang memanfaatkan teknologi. Internet dan media sosial adalah sebagai alat utama dalam pendistribusian informasi. Secara global hal ini telah mengubah wajah media secara keseluruhan. Munculnya media baru memungkinkan terjadinya interaksi dua arah antara pengirim dan penerima informasi. Sebelumnya dalam media konvensional, komunikasi yang terjadi adalah satu arah. Penerima pesan hanya diposisikan sebagai konsumen dari informasi yang didistribusikan oleh media. Kemunculan media baru yang berbasis Web 2.0 dengan memanfaatkan jaringan internet dan media sosial memungkinkan komunikasi, antara pengirim yang memproduksi dan mendistribusikan informasi dengan penerimanya dalam waktu singkat dan bersamaan. Era media baru saat ini juga telah memberi kebebasan kepada setiap orang untuk berekspresi, terlibat dalam aktivisme politik, dan menyebarkan informasi kepada publik. Kehadirannya telah membuka ruang yang selama ini tidak dapat disediakan oleh media konvensional.

Sebagian besar masyarakat Indonesia telah memanfaatkan media sosial sebagai sarana berbagi informasi. Mulai dari mahasiswa, karyawan, menteri, hingga presiden memiliki akun media sosial seperti Facebook dan Twitter. Media sosial seperti membentuk dunia baru hanya dengan berbagi informasi. Melalui status, video serta foto di media sosial keadaan di belahan dunia lain dapat diketahui. Perkembangan internet membuat semua orang memiliki kesempatan yang sama untuk memanfaatkannya, termasuk untuk melakukan pergerakan dan perubahan. Hal ini didukung dengan semakin banyaknya media sosial seperti Facebook, Twitter, Youtube, dan lainnya yang mentransformasi gagasan dan mengubah cara berinteraksi individu dengan menggunakan internet.

Di Indonesia pengguna Twitter sudah mencapai 29,4 juta, jumlah yang hampir menyamai total jumlah penduduk Provinsi
Sumatra Utara 12,3 juta, DKI Jakarta 9,6 juta, dan Banten 9,03 juta (Semiocast, 2012). Pengguna Twitter di Indonesia didominasi oleh mereka yang berumur 15-39 tahun, yang merupakan sekitar 95 persen dari pengguna internet di Indonesia (Nielsen, 2011). Terlihat bahwa bagian terbesar pengguna media sosial adalah kaum muda.

Sementara itu, pengguna Facebook di dunia pada tahun 2012 mencapai 959.000.380. Amerika Serikat muncul sebagai negara pengguna terbesar, sedangkan Indonesia menyumbang 50.227.060 ID (Socialbaker, 2012). Angka tersebut menempatkan Indonesia sebagai negeri terbesar ke empat pengguna Facebook di seluruh dunia dan memberikan sinyal positif bagi proses demokrasi di Indonesia. Jika dikelompokkan berdasar usia, 18-24 tahun merupakan pengguna terbanyak yaitu 42 persen, kemudian usia 25-29 tahun sebanyak 21 persen. Kedua rentang usia tersebut dianggap mempunyai kekuatan aktivisme sosial politik yang terus meningkat. Sedangkan 13-17 tahun sesungguhnya adalah kelompok usia terbanyak kedua yakni 28 persen, namun kelompok ini tidak berdampak signifikan terhadap dinamika politik Indonesia, mengingat belum dianggap sebagai pemilih dalam pemilu (Priyono, AE, 2014: 18).

Proses distribusi informasi, akses, dan dukungan ataupun kritik dapat disebarkan, diterima dan direspons dengan cepat. Kondisi tersebut dibuktikan dengan beberapa kasus misalnya petisi online dari change.org atau tagar \#kawalpemilu, \#saveKPK, dan \#saveahok yang sempat mendapat banyak dukungan (Tribun, 2015). Dengan tingginya pengguna media sosial di Indonesia semakin terbuka luas kesempatan untuk memanfaatkan ia sebagai forum diskusi dan ruang konsilidasi dari berbagai macam gerakan masyarakat.

Sejalan dengan semakin berkembangnya media sosial, perilaku masyarakat dalam memanfaatkannya juga berubah. Seperti yang ditulis oleh Manuel Castell (2010), percepatan 
arus teknologi informasi, terutama pada media sosial telah memberikan sarana yang luas bagi masyarakat untuk mengekspresikan sikap mereka, baik itu dalam bentuk gerakan sosial baru maupun sebagai pengontrol terhadap perilaku para pejabat atau politisi. Misalnya, gerakan media sosial yang muncul di Indonesia pada tahun 2009 bertajuk "Dukungan Bagi Ibu Prita Mulyasari", "Cicak versus Buaya", yang melibatkan KPK dengan petinggi POLRI. Media sosial seperti Facebook dan Twitter kini menjadi pilihan utama masyarakat Indonesia dalam melakukan gerakan sosial baru (Berdikari Online, 2012). Dalam lingkup yang lebih luas, media sosial juga dimanfaatkan oleh masyarakat dunia sebagai tempat berbagi kegiatan sehari-hari sampai dijadikan ruang protes atau kritik, bahkan tuntutan revolusi. Jatuhnya Presiden Mesir Husni Mubarok, misalnya diduga berawal dari gerakan sosial melalui jejaring media sosial Facebook dan Twitter (Aljazeera, 2011).

Sebelum terdapat gerakan sosial baru, internet mungkin hanya dianggap sebagai dunia maya. Tetapi sekarang masyarakat memanfaatkan internet untuk mentransformasikan berbagai aksi kritik nyata dari dunia maya (online) ke dalam dunia nyata (offline), seperti dalam bentuk gerakan media sosial. Anthony Giddens menyatakan bahwa gerakan sosial merupakan upaya kolektif untuk mengejar kepentingan bersama, gerakan mencapai tujuan bersama, atau gerakan bersama melalui tindakan kolektif di luar lingkup lembaga-lembaga yang mapan (Putra, 2006). Robert Misel mendefinisikan gerakan sosial sebagai perangkat keyakinan dan tindakan yang tidak terlembaga, yang dilakukan oleh sekelompok orang untuk memajukan atau mengalangi perubahan dalam masyarakat (Misel, 2004: 6-7). Sedangkan menurut Ernesto Laclau dan Chantal Mouffe gerakan sosial baru merupakan awal pencarian atas kemandekan dari pendekatan Marxis (Fakih, 1996: 46). Pandangan gerakan sosial baru muncul sebagai alternatif dari gerakan sosial lama berbasis pandangan Marxis tradisional yang selalu menekankan pada masalah perjuangan kelas yang terdikotomi menjadi kelas borjuis dan kaum proletar. Menurut Mouffe dalam Fadhillah dan Novi Adrianthy (2009), sedangkan didalam bukunya Hegemony and Socialist Strategy Chantal Mouffe menuliskan bahwa dalam gerakan sosial tidak ada hubungan yang logis untuk bergabung dalam melakukan sebuah gerakan sosial (Laclau dan Mouffe. 2001: 86-87) yang menjadi semangat dari gerakan ini adalah suatu nasib yang sama dan ingin diperjuangankan demi perubahan. Aktor penggerak gerakan sosial baru berasal dari golongan kelas menengah, kaum intelektual, dan unsur-unsur kelas menengah lama petani dan pemilik toko. Pada dasarnya bahwa gerakan sosial yang digerakkan oleh berbagai macam golongan kelas berlandaskan pada sikap altruis di mana mereka melakukan gerakan sosial dengan ikhlas tanpa mengharapkan imbalan, yang menjadi tujuan utama dari gerakan sosial ini adalah suatu perubahan secara luas di dalam masyarakat, maka dari itu kesukarelawanan dalam gerakan sosial sangat berkaitan erat terutama gerakan-gerakan sosial yang terjadi di Indonesia.

Kesukarelawanan di Indonesia sendiri mempunyai sejarah yang cukup panjang. Salah satunya disaat terjadinya gerakan reformasi di tahun 1998, yang merupakan gerakan kesukarelawanan terbesar dan sekaligus gerakan yang menentukan jalannya demokrasi sampai hari ini. Jika dilihat secara lebih mendalam, kesukarelawanan lama hanya dilakukan dalam lingkup ruang nyata, seperti gerakan kesukarelawanan masyarakat yang membantu korban bencana alam di mana ruang aktivitas masyarakat jelas di daerah yang terjadi bencana alam. Kesukarelawanan baru tidak hanya dilakukan dalam lingkup ruang nyata (offline), tetapi juga dilakukan dalam ruang online melalui media sosial. Contohnya, 
gerakan Jalin Merapi disaat erupsi gunung Merapi menggunakan Twitter untuk mencari bantuan logistik. Dengan menggunakan media sosial upaya mereka banyak mendapat perhatian sukarelawan yang ingin membantu para korban erupsi Gunung Merapi. Banyak informasi di retweet oleh pengikut akun Jalin Merapi sehingga cepat tersebar luas di media sosial. Implikasinya bentuk dukungan dari para sukarelawan juga berlanjut ke ruang offline berupa bantuan logistik (Nugroho, 2012: 93-97). Gerakan sosial yang dimotori oleh relawan ini menciptakan pandangan baru dalam memanfaatkan media sosial dalam mendistribusikan pesan sebagai pendorong masyarakat untuk ikut berkontribusi juga dalam gerakan yang diinisiasi oleh relawan.

Perkembangan teknologi informasi, khususnya media sosial juga dimanfaatkan oleh kaum muda yang terhimpun dalam komunitas-komunitas yang bergerak dalam berbagai isu di Yogyakarta. Berbagai komunitas ini menggunakan media sosial sebagai media berbagi aktivitas mereka kepada publik. Media sosial juga digunakan untuk mencari dukungan publik terhadap apa yang telah mereka lakukan mulai dari rekrutmen hingga menggerakkan komunitas. Komunitas juga menggunakan media sosial sebagai alat untuk menjaga eksistensi mereka dalam dunia online. Pada akhirnya kita dapat melihat bagaimana media sosial ini digunakan oleh kaum muda dalam membentuk aktivisme mereka baik itu dalam realitas online maupun offline.

\section{Metode}

Penelitian media baru ini menggunakan pendekatan kualitatif, di mana untuk memahami apa yang dialami oleh subjek dari penelitian ini adalah dengan mendeskripsikan hasil temuan data.Sedangkan dalam penelitian kualitatif yang menjadi obyek utamanya adalah manusia atau segala sesuatu yang dipengaruhi oleh manusia (Indranata, 2008: 4). Metode pengumpulan data berupa in-depth interview serta focus group discussion untuk memperoleh data primer dengan melibatkan dua belas komunitas di Yogyakarta yang bergerak dalam bidangbidang baik itu sosial, lingkungan, ataupun pendidikan. Penulis lebih cenderung memilih isu sosial, lingkungan dan pendidikan, karena ketiga isu ini dianggap merepresentasikan isuisu yang lain terutama isu politik. Misalnya, gerakan bidang sosial oleh komunitas Jalin Merapi pada kasus erupsi gunung Merapi dan gerakan di bidang pendidikan oleh GMM di saat erupsi gunung Merapi menghancurkan sekolah di wilayah Cangkringan, komunitas ini turun untuk mengisi kekosongan peran yang ditinggalkan oleh pemerintah. Hal ini cukup menegaskan bahwa dimensi ruang publik terutama di media sosial sudah menyentuh wilayah politik dan isu-isu dalam bidang lainnya. Sedangkan unit analisis penelitian media baru ini adalah komunitas kaum muda yang berada di Yogyakarta dalam aktivisme gerakan kesukarelawanan mereka memanfaatkan media sosial sebagai sarana media publikasi aktivisme komunitas.

\section{Kebangkitan Komunitas Kaum Muda}

Kaum muda memiliki kesempatan yang sangat terbuka untuk menggunakan media sosial sebagai ruang untuk mengembangkan kegiatan mereka seperti dalam pemberdayaan masyarakat dan mengembangkan diri sebagai bagian dari masyarakat sipil. Kaum muda sebagai agen perubahan serta sekaligus pengawas terhadap jalannya pemerintahan menjadikan media baru sebagai ruang pemantau kinerja pemerintah. Media baru juga digunakan kaum muda sebagai ruang diskusi sampai kritik terhadap kebijakan pemerintah. Komunitas kaum muda tidak hanya sekedar aktif dalam dunia online, tetapi juga melakukan gerakan di dunia nyata. Dengan memanfaatkan media sosial komunitas yang digerakkan oleh kaum muda mencoba merespons permasalahan yang ada di masyarakat, mencari dukungan masyarakat, dan melakukan aktivisme 
online. Di antara komunitas kaum muda di Yogyakarta itu adalah komunitas Jalin Merapi yang bergerak di saat terjadi bencana erupsi Gunung Merapi, Young on Top, Festival Film Dokumenter (FFD), Jendela, Gerakan Gadjah Mada Mengajar (GMM), Book for Mountain (BFM), Koalisi Pemuda Hijau (KOPHI), Ketjil Bergerak, Jogja Berkebun, Ikatan Mahasiswa Muhammadiyah (IMM), Coin A Change dan Kampung Cyber.

Dengan adanya media sosial kaum muda yang tergabung dalam komunitas dapat dengan mudah berdikusi dan melakukan konsolidasi dengan anggota sesama komunitas, media sosial telah memfasilitasi ruang publik bagi kaum muda, didukung dengan semakin meningkatnya digital native yang membuat ruang publik media sosial menjadi pop-culture baru.

\section{Public Sphere dan Digital Native}

Salah satu corak masyarakat pascaindustrial ditandai dengan proses interaksi yang didominasi oleh penggunaan teknologi informasi. Informasi saat ini telah dianggap sebagai aset dan mempunyai fleksibilitas untuk menyebar cepat dengan difasilitasi oleh media sosial. Dalam fungsi tersebut media sosial dapat dianggap turut menciptakan ruang publik baru. Ruang publik media sosial tersebut telah berkembang di tengah masyarakat, ditandai dengan munculnya berbagai forum yang digunakan untuk mendiskusikan permasalahan tertentu yang telah lampau ataupun isu yang sedang terjadi ditengah masyarakat. Pada dasarnya public sphere atau ruang publik digunakan sebagai tempat di mana sejumlah orang berkumpul untuk saling berdiskusi, seperti dalam musyawarah (offline). Yang terjadi saat ini, media sosial telah mampu menyediakan ruang publik untuk berdiskusi tanpa harus bertemu secara langsung (online). Hal ini senada dengan pernyataan Jürgen Habermas tentang ruang publik. Habermas melihat ruang publik sebagai tempat di mana masyarakat sebagai pembawa opini publik yang berfungsi sebagai hakim yang kritis terhadap permasalahan yang ada (Habermas. 1989:2-3), di dalam ruang publik tentu saja isu yang menjadi bahan perdebatan dan pembahasan terlepas dari permainan media massa yang kini telah menjadi salah satu bisnis permainan informasi khususnya di Indonesia. Terdapat penulis lain yang menjelaskan tentang hal yang sama mengenai ruang publik Habermas, dijelaskan bahwa ruang publik adalah suatu wilayah dalam kehidupan sosial yang memungkinkan tiap warga negara berbicara dan terlibat dalam berbagai silang pendapat serta secara bersama-sama membentuk pendapat umum (Sugihartati, 2014: 42). Pada dasarnya pemikiran Habermas menjelaskan juga bahwa ruang publik merupakan ruang politik di mana segala bidang isu dapat di bahas dan diperdebatkan secara luas oleh masyarakat, hal ini lah yang menjadi fokus dari penelitian media baru yang mampu menyediakan ruang publik bagi masyarakat secara online.

Dengan ruang publik tersebut diharapkan masyarakat dapat membangun pendapat dan mengutarakan kritik mereka terhadap pemerintah. Misalnya, ketika mobil Menteri Sosial memasukijalur bus Transjakarta, kejadian tersebut diabadikan oleh warga yang lalu di sebarluaskan melalui akun Twitter-nya. Dengan cepat informasi tersebut mendapat respons dari publik, bahkan sang menteri mengklarifikasi tindakan yang dilakukannya itu (Nugroho, 2012: 71). Ruang publik di media sosial telah menjadi pengontrol terhadap perilaku penguasa. Masyarakat ikut mengutarakan pendapat mereka dan memperjuangkan serta mencari dukungan melalui media sosial. Ini tergantung pada bagaimana cara mendistribusikan informasi tersebut kepada publik:

\footnotetext{
"Bagaimana media baru digunakan sebagai sarana untuk memfasilitasi tindakan atau aktivisme, baik itu sosial maupun politik, tapi juga ada temen-temen yang menggunakan media baru untuk memproduksi dan
} 
mendistribusikan informasi." - Wisnu Martha (data FGD 15 November 2013).

Digital native adalah sebutan bagi generasi muda yang dibesarkan dan terbiasa dengan teknologi informasi dan komunikasi berbasis digital (Sugihartati, 2014: 37). Kaum muda ini merupakan user (pengguna) dari teknologi informasi yang merupakan bagian dari digital native. Mereka merupakan generasi yang tumbuh dengan menggunakan telepon seluler (ponsel) dan internet sebagai sarana untuk memperbarui informasi.

Distribusi ilmu pengetahuan sudah mulai bergeser dari media konvensional berupa media cetak menjadi media digital yang tidak menghasilkan limbah kertas. Efektifitas dalam mengakses media digital menjadikan media konvensional mulai terpinggirkan. Twitter misalnya, semua informasi sangat cepat didistribusikan: hanya dengan me-retweet satu berita, maka akan dapat dilihat oleh seluruh pengikut akun kita. Media pembelajaran melalui media sosial seperti yang dilakukan Young on Top sangat efektif bila mengingat media ini begitu mudah diakses oleh pengguna sosial media lain.

\section{Aktivisme dan Kesukarelawanan dalam Media Sosial}

Media sosial telah membuka ruang baru bagi penggunanya. Ruang tersebut berupa dimensi yang masih bersifat netral, yang belum ada komponen-komponen yang mengisinya. Dalam hal ini yang menentukan adalah pengguna media sosial, dengan tujuan pemanfaatan media sosial. Komponenkomponen dari tujuan itu yang membentuk fungsi dari ruang di dalam media sosial. Media sosial telah memberikan ruang tersendiri bagi para penggunanya. Aktivis media sosial memanfaatkan ruang tersebut untuk melancarkan gerakan mereka. Dunia maya telah mengubah kaum muda dalam perkembangan gerakan masyarakat sipil karena ruang publik yang tercipta di dunia maya mempengaruhi pengguna media sosial lain dalam menanggapi isu yang ada di berbagai bidang.

\section{Lingkungan}

Koalisi Pemuda Hijau (KOPHI) merupakan komunitas yang bergerak dalam bidang lingkungan hidup. Komunitas ini gencar mengampanyekan gerakan mereka melalui media sosial. Mereka mengajak masyarakat luas, khususnya kaum muda, untuk lebih memperhatikan lingkungan dengan tindakan yang dilakukan secara kolektif dan berkelanjutan. Hal ini bertujuan untuk menciptakan lingkungan hidup yang lestari. Selain itu KOPHI juga pernah membuat petisi yang ditujukan kepada PT. Sinar Sosro yang mendesak untuk menyediakan water dispenser berbayar untuk botol minum, mengajak masyarakat untuk melestarikan cadangan air melalui kegiatan biosafari serta menekankan pemahaman mengenai teknologi yang seharusnya lebih mendekatkan kepada alam (KOPHI, 2014). Selain KOPHI, terdapat juga komunitas-komunitas lain yang bergerak dalam bidang lingkungan, seperti Jogja Berkebun yang aktif mengampanyekan pengetahuan mengenai lingkungan dengan cara berkebun. Media sosial telah menjadi salah satu ruang yang dimanfaatkan oleh komunitaskomunitas kaum muda tersebut sebagai media pembelajaran kepada publik:
"Dengan prinsip bahwa kesadaran itu menular, kita berusaha untuk memanfaatkan media Twitter ini sebagai saluran kita ke masyarakat, minimal kepada mereka yang mem-follow kami." - Jogja Berkebun (Data FGD, 15 November 2013).

Persinggungan antara realitas online di dunia maya dan realitas offline di dunia nyata tidak dapat dipisahkan. Pengalaman KOPHI dan Jogja Berkebun di dunia nyata 
menjadi referensi dan landasan tersendiri bagi kaum muda dalam apa yang mereka gerakkan di dunia online. Seperti halnya pengetahuan yang didistribusikan melalui media sosial turut menjadi landasan yang mempengaruhi aktivitas kaum muda di dunia nyata, realitas online mempengaruhi realitas offline, begitu juga sebaliknya. Kondisi ini mempengaruhi kesadaran pemuda dalam memanfaatkan ruang media sosial sebagai tempat untuk menciptakan informasi dan mendistribusikannya dari pengalaman mereka baik itu secara online ataupun offline.

\section{Pendidikan}

Gerakan Gadjah Mada Mengajar merupakan salah satu komunitas yang memanfaatkan media sosial sebagai media publikasi kegiatan mereka. Mulai dari berbagi informasi maupun isu sampai rekrutmen mereka memanfaatkan media sosial, sehingga isu yang mereka bagi dapat dilihat oleh masyarakat. Hanya dalam hitungan menit isu tersebut telah menyita banyak sekali perhatian dari masyarakat. Kaum muda tidak hanya sekedar membagi informasi dari kegiatan mereka ke dalam media sosial tetapi mereka juga berusaha bagaimana mengolah ruang tersebut menjadi lebih menarik dengan berbagai kombinasi isi yang disediakan oleh media sosial.

"Kondisi sekolahnya juga sangat miris sekali gitu, nah dari situ media yang kita pakai sama, kita ngambil gambar jadi itu nanti bersambung, kira-kira sekarang menceritakan kondisi jalan, besok menceritakan apa, besok menceritakan apa lagi, nah di gambar itulah, gambar kita posting bawahnya ada deskripsinya gitu, itu kan membuat orang penasaran, dan itu setiap hari kita update lagi, kita update kondisi gurunya bagaimana, muridnya bagaimana gitu." - Gadjah Mada Mengajar (Data FGD, 15 November 2013).

\section{Gambar 1. \\ Foto Kegiatan \#IuRUN di Semarang}
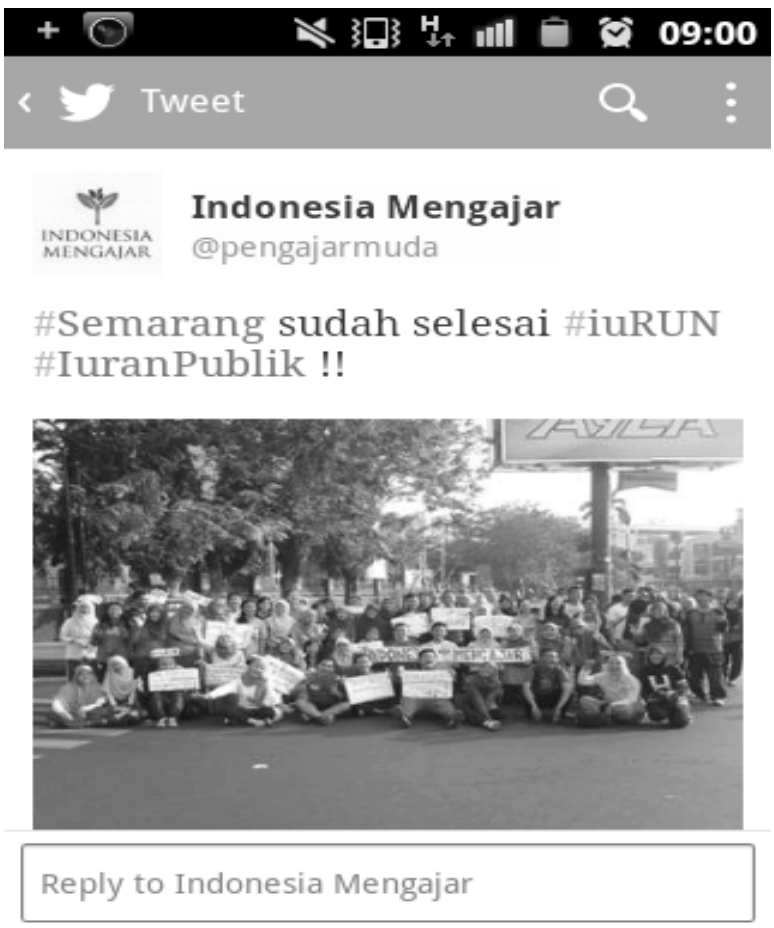

Dalam membentuk aktivisme relawan, media sosial komunitas biasanya menggunakan beragam isi berupa foto, video, serta teks untuk menarik perhatian relawan. Beragam isi tersebut dapat menggambarkan situasi yang terjadi di lapangan sehingga dapat menjadi salah satu daya tarik untuk komunitas dan juga untuk menjaga eksistensi komunitas mereka di dunia online. Bermodalkan informasi dari media sosial para relawan ini tidak hanya aktif membagi informasi dalam dunia online, tetapi mereka juga aktif dalam memberikan bantuan sesuai yang dibutuhkan oleh masyarakat pada dunia offline, seperti yang dilakukan komunitas Book for Mountain. Komunitas ini menjembatani para relawan dalam ikut dan memberikan sumbangan berupa buku untuk anak-anak di Lombok.

\section{Sosial}

Masalah sosial masih menjadi isu yang sensitif dalam artian cepat mendapatkan respons dari masyarakat khususnya di kalangan 
pengguna media baru. Dengan tingkat sensitivitas yang tinggi, sebuah isu sosial akan cepat mendapat berbagai tanggapan dari publik karena isu ini menyangkut kehidupan masyarakat luas. Dengan tingginya jumlah pengguna media sosial bukan hal yang mustahil jika isu tersebut akan mendapat perhatian publik dalam hitungan menit. Hal ini teruji disaat penanganan bencana di Yogyakarta pada tahun 2010, di mana aktor penggeraknya adalah komunitas Jalin Merapi yang memanfaatkan ruang media sosial dalam gerakan komunitas mereka dengan cara membagi kepada publik situasi dan kondisi para pengungsi korban Merapi yang kekurangan makanan, baju dan selimut. Hanya dalam hitungan menit banyak dari warga sekitar Yogyakarta menanggapi tweet yang dibuat komunitas Jalin Merapi dan menawarkan bantuan logistik kepada para pengungsi.

"Sebetulnya karena dari Merapi mengalami erupsi. Ada sebuah eksperimentasi yang teruji ketika situasi emergency. Semua orang tidak pernah bertanya kamu siapa, kamu ngomong gitu emangnya kamu siapa. Jadi, siapapun bisa menyampaikan atau bisa men-share, tentang apapun selama itu terkait dengan aktifitas penanganan korban bencana. Tapi kalo udah situasi normal, lain ceritanya" - Jalin Merapi (Data FGD 15 November 2013).

Media sosial telah berhasil membentuk aktivisme kesukarelawanan penggunanya berdasarkan isu dan informasi yang tersebar luas di dalam ruang tersebut. Hal ini menandakan bahwa ruang di media sosial sangat efektif dalam menyebarkan informasi dan isu kepada masyarakat luas.

\section{Penggunaan Media Sosial dan Gerakan Komunitas Kaum Muda Yogyakarta}

Dalam praktiknya, penggunaan media sosial oleh komunitas kaum muda di Yogyakarta umumnya sebagai media publikasi dari kegiatan komunitas. Selain itu media sosial juga menjadi salah satu cara untuk menjaga eksistensi komunitas mereka di dalam dunia online. Pemahaman dari semua responden mengatakan bahwa media sosial adalah alat untuk berkomunikasi tanpa harus bertemu secara langsung untuk melakukan interaksi. Mayoritas dari responden adalah pengguna media sosial sejak duduk di bangku Sekolah Menengah Atas. Ini menandakan bahwa mereka sudah terbiasa dengan media sosial seperti Friendster dan Mxit sebelum memasuki bangku kuliah sehingga dapat dikatakan bahwa mereka termasuk dalam net generation. Jika net generation sebutan bagi generasi Internet di mana segala aktivitas mereka merujuk pada teknologi berbeda halnya dengan digital native yang berarti bahwa tahun lahirnya generasi tersebut bersamaan dengan perkembangan digital.

\section{"Media sosial adalah suatu komunikasi atau penyampaian pesan dari satu orang ke orang yang lainnya bisa secara tertulis, visual, audio maupun audiovisual melalui media online yang tidak terbatas ruang dan waktu, yang tidak memerlukan pertemuan tatap muka secara langsung sehingga dapat melakukan komunikasi satu sama lain tanpa mengabaikan kepentingan lain karena penggunaan media sosial dilakukan dengan menyesuaikan kegiatan/kepentingan lain." - Mawar (data wawancara, 11 September 2014).}

Mayoritas informan mengatakan bahwa media sosial mereka gunakan sebagai media untuk memperbarui informasi dalam berbagai isu yang sedang berkembang. Selain itu media sosial mereka manfaatkan sebagai ruang diskusi sesama mereka untuk membahas isu yang sedang tren.

Mayoritas komunitas di Yogyakarta merupakan gerakan kesukarelawanan, 
kebanyakan dari mereka adalah mahasiswa. Sebagian besar informan yang tergabung dalam komunitas memiliki motivasi yang bersifat altruis, di mana mereka melakukan kesukarelawanan dengan ikhlas dalam membantu orang lain yang mereka anggap kurang beruntung. Mayoritas informan mengatakan bahwa dalam melakukan gerakan yang nonprofit diperlukan semangat dan visi misi yang jelas, karena jika tidak gerakan yang dilakukan tidak akan bertahan lama.

"Gerakan sosial itu suatu gerakan dari perkumpulan/komunitas untuk melakukan perubahan/perbaikan keadaan sosial agar menjadi lebih baik" - Mawar (data wawancara, 11 September 2014).

Kaum muda merupakan agen perubahan dalam masyarakat di mana mereka merespons permasalahan dan membantu untuk mencapai kepentingan masyarakat. Untuk melakukan gerakan sosial juga diperlukan kesadaran secara pribadi yang dapat menular kepada orang lain. Sekalipun nonprofit, tetapi jika dengan kesadaran untuk menciptakan keadaan yang lebih baik maka gerakan sosial itu dirasa akan tetap bertahan lama.

Memanfaatkan media sosial dalam gerakan, baik secara sadar atau tidak, telah menciptakan ruang bagi mahasiswa ataupun kaum muda lain untuk dapat terlibat dan berpartisipasi di dalam gerakan. Media sosial dipilih karena murah dan yang paling dekat dengan kaum muda. Misalnya, GMM memanfaatkan media sosial sejak pertama kali berdirinya untuk publikasi kegiatan mereka. Dengan menggunakan media sosial GMM menyebarkan semangat mengajar mereka dengan melalui foto dan video yang mereka unggah ke media sosial. GMM sendiri memiliki divisi media dan publikasi yang bertugas untuk memperbarui segala informasi tentang GMM di media sosial seperti Facebook dan Twitter.
"Caranya, penggunaan website, fanpage, FB dan Twitter. Menuliskan profil GMM, orang-orang yang ada di dalam komunitas GMM, foto-foto kegiatan yang menjadi kunci eksistensi gerakan." - Mangga (data wawancara, 11 September 2014).

Selain digunakan untuk membagi informasi mengenai kegiatan GMM, media sosial juga dimanfaatkan oleh kaum muda di GMM sebagai ruang untuk konsilidasi gerakan mereka. Dengan media sosial sudah tidak diperlukan bertemu secara langsung untuk mengadakan rapat lebih menghemat waktu dan tenaga. Mayoritas informan mengatakan bahwa media sosial lebih efektif dibandingkan dengan media konvensional yang terlalu rumit dan memakan waktu lama dalam prosesnya.

Tantangan penggunaan media sosial terlihat begitu jelas. Dengan pengguna yang semakin banyak, terutama kaum muda, maka akan sulit untuk mengontrol mereka dalam menggunakan dan memanfaatkan media sosial. Mayoritas informan mengatakan bahwa peluang yang dimiliki media sosial dalam membentuk gerakan di masa depan sangat terbuka lebar karena kaum muda sudah banyak yang memanfaatkan media sosial sebagai media komunikasi dan pembaharuan informasi. Selain itu, terdapat informan yang mengatakan bahwa mudahnya membuat akun, akan menimbulkan akun palsu, semakin banyak yang mengatas namakan organisasi atau perorangan sehingga rentan kejahatan untuk membedakan akun resmi dari suatu komunitas dapat dilihat seberapa banyak pengikut dan aktifnya akun tersebut di media sosial dalam memperbaharui informasi mengenai kegiatan mereka.

\footnotetext{
"Mungkin ada istilah besarnya sebuah organisasil gerakan sosial bisa dilihat dariakun media sosialnya." - Mangga (data wawancara, 16 September 2014).
} 
Menurut informan Mangga bahwa tantangan media sosial di masa depan dalam membentuk gerakan sosial dirasa sangat sulit. Jika media sosial hanya dijadikan alat untuk menyebarkan informasi dan menjaring masa dirasa masih sangat mungkin, tetapi gerakan sosial di media online mustahil dapat terwujud karena masih terdapat orang-orang yang hanya ikutan meramaikan di media sosial ketika gerakan nyata mereka tidak hadir, sedangkan untuk komunitas kaum muda di Yogyakarta seperti GMM (Gadjah Mada Mengajar) informan Mangga menyatakan bahwa di dalam komunitas tidak menampik terdapat anggota yang aktif di media sosial bahkan ada yang hanya mencari eksistensi di media sosial hanya dengan aktif di media sosial tetapi di aktifitas offline-nya pasif bahkan tidak berkontribusi. Mayoritas informan berharap bahwa media sosial di masa depan menjadi media yang dapat menginspirasi khalayak ramai melalui isu-isu yang tersebar luas di dalamnya.

Tingkat pengguna media sosial tercatat begitu tinggi di Indonesia. Percakapan atau distribusi informasi, khususnya di Facebook, bisa mencapai 5,02 juta update status per hari dengan asumsi 2 persen dari pengguna aktif Facebook berada di Indonesia (SocialBaker, dalam Wasesa, A. Silih 2013). Sedangkan untuk aktivitas Twitter mencapai 7,35 juta tweets/re-tweets perharinya dengan rata-rata 5 persen dari pengguna aktif (comScore, dalam Wasesa, A. Silih 2013). Dengan angka pengguna dan tingginya aktivitas baik itu percakapan maupun pemberitaan di media sosial, ia menjadi sangat efektif dalam penyebaran informasi dan mencari dukungan. Mereka yang pada realita offline tidak memiliki kekuatan politik dapat menggunakan media sosial untuk mencari dukungan publik. Di sini, media sosial telah memfasilitas tindakan mereka dalam realitas online yang akan mempengaruhi juga dalam membentuk aktivisme mereka di realitas offline.

\section{Aktivitas Media Sosial dari “Tahu” hingga "Terlibat"}

Media baru telah memungkin penggunanya untuk aktif dalam berinteraksi dengan pengguna lainnya, sehingga pertukaran atau distribusi informasi tidak bersifat satu arah dari penyedia informasi kepada pengguna informasi. Media baru lebih unggul dalam hal kecepatan distribusi informasi di bandingkan dengan media konvensional. Pengguna Internet di Indonesia sekitar 55 juta orang (Kemp, 2012), yang terbesar di Asia Tenggara. Sebagian besar dari jumlah ini mengakses internet melalui ponsel mereka. Secara tidak langsung media sosial telah memberikan ruang untuk masyarakat dalam berinteraksi dan berdiskusi terhadap masalah atau isu yang sedang terjadi. Ruang ini menjadi sangat riskan dimasuki oleh isu-isu yang sensitif karena dengan kecepatannya media sosial dapat mengubah isu dari yang sifatnya biasa menjadi populer di kalangan pengguna media sosial. Merespons hal tersebut sepertinya mereka menyukai aktivisme online daripada offline, ini terlihat dalam penyataan informan saat wawancara sebagai berikut:

\section{"Kalau petisi online sering, tapi kalau demo saya anti karena menurut saya demo kurang ada manfaatnya." - Jambu (data wawancara, 14 September 2014).}

Aktivisme kaum muda di media sosial sebagian besar dijalankan menggunakan ponsel yang semakin mempermudah kaum muda untuk memperbarui informasi yang mereka butuhkan, (Nielsen, 2011). Bagi bagi informan sendiri media sosial telah bermanfaat sebagai ruang untuk mencari informasi dan berjejaring dengan sesama pengguna media sosial lainnya. Demonstrasi sebagai media dalam menyampaikan aspirasi dan kritik pun sudah mulai ditinggalkan, saat ini telah banyak petisi online yang menampung suara 
dan aspirasi masyarakat, misalnya change.org. Adapun salah satu contoh peralihan medium aspirasi dan kritik tersebut ditunjukkan saat aksi penyerahan petisi change.org bertema "serahkankeKPK" oleh penggiat anti korupsi yang dilakukan intelektual dan mahasiswa pada tanggal 4 Oktober 2012, yang diterima ketua KPK Abraham Samad dan wakil ketua KPK Busyro Muqqodas, mereka meyerahkan satu kardus besar berisi nama-nama pendukung petisi yang berjumlah 5.000 orang, yang kemudian oleh Busyro menamai tindakan mereka sebagai "semut rang-rang" (Priyono, AE, 2014: 3).

Menurut informan Jambu media sosial tidak hanya memiliki kecepatan dalam mendistribusikan informasi tetapi juga mempunyai pengaruh dalam membentuk aktivisme kaum muda untuk dapat bergabung contohnya dalam gerakan komunitas Gadjah Mada Mengajar. Ini dapat dilihat dari banyaknya orang yang bertanya mengenai GMM dan peningkatan dari jumlah relawan, yang tidak terlepas dari peran media sosial sebagai media publikasi yang digunakan oleh GMM.

"Setelah penggunaan media sosial sering banyak orang bertanya dan terjadi peningkatan relawan, dulu waktu angkatan aku relawan paling 5 orang setelah itu meningkat jadi 15 orang." - Jambu (data wawancara, 13 September 2014).

Dapat dikatakan bahwa peningkatan jumlah relawan GMM merupakan salah satu pengaruh dari keberhasilan penggunaan media sosial. Secara tidak langsung media sosial telah berhasil membentuk aktivisme relawan kaum muda untuk dapat ikut bergabung dan berbagi ilmu pengetahuan. Ini juga didukung oleh pendapat informan Mangga. Ia mengatakan bahwa menggunakan media sosial dalam gerakan GMM lebih efektif, di dalam media sosial terdapat banyak fitur yang dapat membuat informasi atau isu dikelola menjadi semakin menarik. Oleh karena itu, tidak mengherankan jumlah relawan semakin meningkat disaat publikasi menggunakan media sosial.

"Peningkatan jelas ada, karena
dimulai dari feedback mereka ketika
kita mengupload foto-foto kegiatan dan
itu menjadi alat ransang kesadaran
sosial mereka, meskipun ada juga yang
karena ingin menunjukan eksistensi
dirinya sebagai orang dengan nilai sosial
tinggi." - Mangga (data wawancara,
16 September 2014).

Mayoritas informan mengatakan bahwa mereka pertama kali mengetahui GMM melalui media sosial. Mereka menganggap bahwa media tersebut sangat efektif dalam membentuk aktivisme mahasiswa melalui isu dan informasi yang terdapat di dalamnya dan akan mempengaruhi sikap dari pengguna media sosial. Pembentukan aktivisme yang dilakukan oleh GMM juga terlihat dalam membangun kesadaran mahasiswa dengan menggunakan media sosial. Semakin bertambahnya relawan yang bergabung dalam komunitas setiap tahunnya, dapat menjadi salah satu indikator keberhasilan GMM dalam memanfaatkan media sosial dalam membentuk aktivitas mahasiswa dari tahu hingga terlibat dalam aktivitas komunitas mereka.

Pada awalnya semangat membawa perubahan dalam gerakan GMM memang terasa dan terlihat dari tingginya antusias kaum muda, khususnya mahasiswa, untuk dapat bergabung serta melalukan aktivitas dalam melakukan perubahan. Namun semangat itu tidak berlangsung lama mengingat komunitas GMM ini hanya sebagai gerakan kesukarelawanan: tidak ada imbalan berupa materi dalam melakukan aktivitas ini. Informan Duren menyatakan bahwa komitmen dalam melakukan suatu gerakan perubahan sangat penting sehingga kesadaran atau kemauan tersebut sangat diperlukan. Di sini dapat 
dilihat terdapat perbedaan pendapat mengenai arti aktivisme di dalam komunitas GMM, yang melingkupi seluruh anggota komunitas GMM, baik itu ketua, pengurus maupun anggota. Mereka adalah kaum muda yang bergerak dengan kesukarelawanan, tetapi setiap individu yang terlibat di dalamnya tidak memaknai aktivisme kesukarelawanan secara sama sebagaimana terlihat dari aktivitas mereka di dalam komunitas.

Aktivisme yang dibangun oleh aktivis melalui media sosial berhasil dalam menyalurkan ideologi dan sudut pandang aktivis kepada masyarakat sehingga jumlah relawan meningkat. Tetapi terdapat perbedaan disini antara aktivis dengan aktivisme kaum muda. Aktivis adalah individu yang aktif dalam komunitas yang bertujuan untuk melakukan sebuah perubahan yang berlandaskan pada ideologi ataupun nilai tertentu, memegang prinsip dengan kuat dalam melakukan aktivisme, individu-individu tersebut berbeda dengan aktivisme kaum muda, yang sama aktifnya di dalam komunitas, tetapi mereka mungkin mempunyai kepentingan pragmatis sehingga perannya sebagai aktivis mudah tergoyahkan. Mereka tidak mempunyai orientasi yang cukup kuat terhadap tujuan dari gerakan yang dilakukan. Dapat pula dikatakan bahwa aktivisme kaum muda ini hanya sebagai kaum reaksioner yang tidak memandang atau mengkaji suatu isu secara mendalam sehingga aktivisme yang mereka lakukan mudah berhenti di tengah jalan. Seperti yang dikatakan oleh informan Duren, semua ini hanya masalah komitmen. Hal ini juga dapat menjadi alat untuk melihat eksistensi aktivisme yang dilakukan oleh relawan yang lain dengan memanfaatkan media sosial.

\section{Kesimpulan}

Kaum muda yang terhimpun di dalam komunitas telah berhasil dalam menciptakan ruang baru di media sosial untuk memicu sebuah gerakan. Mereka menggunakan ruang di media sosial untuk menyebarkan isu dan informasi mengenai aktivitas mereka. Isu tersebut berhasil menarik pengguna media sosial lainnya dalam bentuk dukungan dan bergabungnya kaum muda ke dalam komunitas. Sebagai contoh, publikasi kegiatan dan rekrutmen menggunakan media sosial tidak hanya dilakukan oleh GMM, tetapi juga oleh beberapa komunitas kaum muda lain di Yogyakarta yang mengusung isu berbeda dengan GMM. Gerakan sosial baru digerakan oleh kaum muda dengan menggunakan media sosial sebagai kekuatan baru, mengingat kaum muda menjadi segmen terbesar pengguna media sosial: kaum muda juga umumnya lebih peka terhadap berbagai isu yang ada di masyarakat. Dengan media sosial kaum muda dapat dengan mudah menyebarkan isu dan informasi, bahkan mencari dukungan publik untuk gerakan mereka.

Banyaknya kaum muda yang bergabung dalam gerakan sosial tidak terlepas dari media sosial sebagai media publikasi mereka. Penggunaan media sosial dalam membentuk gerakan sosial sangat efektif dalam menarik perhatian publik. Ruang publik dalam media sosial telah menjelma menjadi kekuatan publik, di mana segala isu dengan mudah tersebar di dalam media sosial sehingga dapat dijadikan ruang untuk menarik aspirasi masyarakat. Terbukti, telah banyak gerakan sosial yang berawal dari gerakan media sosial. Selain itu, gerakan media sosial juga dapat mengontrol perilaku masyarakat.

Aktivisme kaum muda di media sosial menjadi kekuatan penyeimbang pemerintah, disaat pemerintah tidak dapat menjangkau isu yang ada di masyarakat dengan media sosial gerakan kaum muda mengangkat isu itu ke publik, sehingga menjadi isu yang mendapatkan perhatian publik, gerakan kaum muda ini juga menjadi pengganti peran pemerintah disaat pemerintah lambat dan tidak dapat menjangkau masyarakat kedalam lingkup terkecil di sinilah peran gerakan kaum muda mengisi kekosongan peran yang ditinggalkan pemerintah. 


\section{Daftar Pustaka}

Andrianthy, Novi. (2009). Aktivisme GemkaraBP3KB dan Pengaruhnya Dalam Mewujudkan Kabupaten Batubara, Skripsi, Medan: Universitas Sumatra Utara.

Aljazeera. 14 Februari (2011). Timeline: Egypt's revolution a chronicle of the revolution that ended the three-decade-long presidency of Hosni Mubarak. (Online). (http://www.aljazeera. com/news/middleeast/2011/01/20111251533 4871490.html, diakses September 2014).

BerdikariOnline. 7 Februari 2012. (2013). Dunia Maya dan Gerakan Sosial Anti Korupsi. (Online). (http://m.berdikarionline.com/ editorial/20120207/dunia-maya-dangerakan-sosial-anti-korupsi.html, diakses Oktober 2013).

Castells, Manuel. (2010). The Rise of the Network Society, $2^{\text {nd }}$ edition. UK: John Wiley \& Sons Ltd. (Online). (http://samples.sainsburysebooks. co.uk/ 9781444310146_sample_415190.pdf, diakses 23 Desember 2014).

Fadhillah Putra dkk. (2006). Gerakan sosial, Konsep, Strategi, Aktor, Hambatan dan Tantangan Gerakan Sosial di Indonesia. Malang: PlaCID's dan Averroes Press.

Fakih, Mansoer. (1996). Masyarakat Sipil Untuk Transformasi Sosial, Pergolakan Ideologi LSM Indonesia. Yogyakarta: Pustaka Pelajar.

Habermas, Jurgen. (1989). The Structural Transformation of the Public Sphere. MIT Press.

InternetWorldStats. (2013). Asia Top Internet Countries December 31 2013. (Online). (http:// www.internetworldstats.com/stats3.htm, diakses Februari 2014).

Indranata, Iskandar. (2008). Pendekatan Kualitatif Untuk Pengendalian Kualitas. Jakarta: Universitas Indonesia (UI-Press).

KBBI. (2014). Pengertian Aktivis. (Online). (http:// kbbi.web.id/aktivis, diakses 7 agustus 2014).

Kemp, Simon. (2012). Social, Digital and Mobile in Asia. (Online). (http://wearesocial.sg/ blog/2012/10/social-digital-mobile-asia/, diakses Desember 2013).

KOPHI. (2014). Gerakan KOPHI. (Online). (http://Kophi.or.id/, diakses pada Agustus 2014).

Laclau, Ernest, Mouffe, Chantal. (2001). Hegemony and Socialist Strategy: Towards a Radical Democratic Politics.

Misel, Robert. (2004). Teori Pergerakan Sosial. Yogyakarta: Resist Buku.

Nielsen, (2011). The Digital Media Habits and Attitudes of Shouthest Asian Consumers. (Online). (http://www.slideshare.net/ bingkimpo/the-digital-media-habits-andattitudes-of-southeast-asian-consumersoctober-2011, diakses Oktober 2013).

Nugroho, Yanuar, S.Syarief, Shinta. (2012). Melampaui Aktivisme click? Media Baru dan Proses Politik dalam Indonesia Kontemporer. Jakarta.

Priyono, AE, dkk, (2014), Media Sosial Alat Gerakan Sipil, Public Virtue Institute, Jakarta.

Semiocast. (2012). Top 20 countries in terms of Twitter accounts. (Online). (http://semiocast. com/en/publications/2012_07_30_Twitter _reaches_half_a_billion_accounts_140m_ in_the_US, diakses October 2013).

Sugihartati, Rahma, Perkembangan Masyarakat Informasi dan Teori Sosial Kontemporer, Jakarta: Kencana, 2014.

Tribun Jakarta. 11 Maret, 2015. 4.076 Tagar \#SaveAhok Rajai Kicau Twitter, Siap Gagalkan Manuver Dewan Jegal Gubernur. (Online). (http://www.tribunnews.com/ metropolitan/2015/02/27/4076-tagarsaveahok-rajai-kicau-Twitter-siap-gagalkanmanuver-dewan-jegal-gubernur, diakses 11 Maret 2015).

Wasesa, A.Silih, 5 Juni, (2013). Gossip, Issue and World of Mouth ( $p d f)$. Disampaikan dalam Seminar Nasional UGM. Yogyakarta. 